\title{
Access to health care for patients with thalassaemia in Greece: a cross-sectional study
}

Kyriakos Souliotis, ${ }^{1,2}$ Christina Golna, ${ }^{3}$ Sofia Nikolaidi, ${ }^{2}$ Georgia Vatheia ${ }^{2}$ and Stanimir Hasurdjiev ${ }^{4}$

${ }^{1}$ Department of Social and Education Policy, University of Peloponnese, Corinth, Greece. ${ }^{2}$ Health Policy Institute, Athens, Greece. ${ }^{3}$ Innowth Limited, Larnaca, Cyprus. ${ }^{4}$ Patient Access Partnership, Brussels, Belgium. (Correspondence to: Kyriakos Souliotis: info@ksouliotis.gr; ksouliotis@uop.gr).

\begin{abstract}
Background: The prevalence and clinical burden of beta-thalassaemia in Greece is high. Little information is available on the unmet needs of patients with beta-thalassaemia and barriers to access to care.

Aims: This study investigated barriers that patients with transfusion-dependent beta-thalassaemia in Greece face when accessing care and the associations between socioeconomic factors and access to care.

Methods: A cross-sectional study was conducted between November 2018 and January 2019. The sample consisted of 116 beta-thalassaemia patient-members of two Panhellenic patient associations for people with thalassaemia. All respondents were transfusion-dependent. The survey customized and used the Patient Access Partnership 5As of access tool to measure participants' access to health care services (subscales: accessibility, adequacy, affordability, appropriateness and availability). Data on their socioeconomic characteristics were also recorded. The association between the total score of each subscale and patient characteristics was examined using the Mann-Whitney or Kruskal-Wallis tests.

Results: Respondents considered inpatient services less adequate and appropriate, and outpatient services and laboratory tests less affordable. Outpatient services were also perceived as less available. Participants' income was statistically significantly associated with all the subscales except accessibility, and rural residence was significantly associated with all five subscales.

Conclusion: Barriers in access to health care among beta-thalassaemia patients receiving transfusions still persist, especially for those who live far from transfusion centres and have lower incomes. It is important to understand and map current unmet medical and social needs of beta-thalassaemia patients in Greece, in order to design and implement a targeted health policy that can measurably improve patients' lives.
\end{abstract}

Keywords: beta-thalassaemia, transfusion, health services accessibility, socioeconomic factors, Greece

Citation: Souliotis K; Golna C; Nikolaidi S; Vatheia G; Hasurdjiev S. Access to health care for patients with thalassaemia in Greece: a cross-sectional study. East Mediterr Health J. 2020;26(12):1482-1492. https://doi.org/10.26719/emhj.20.118

Received: 01/11/19; accepted 19/03/20

Copyright (C) World Health Organization (WHO) 2020. Some rights reserved. This work is available under the CC BY-NC-SA 3.o IGO license (https:// creativecommons.org/licenses/by-nc-sa/3.o/igo).

\section{Introduction}

Management of beta-thalassaemia major includes regular blood transfusions and iron chelation therapy to manage iron overload in the body $(1,2)$. Allogeneic haematopoietic stem cell transplantation is the only definitive cure for transfusion-dependent young patients before the development of iron-related tissue damage (3). New therapies are currently in development for the treatment of anaemia and iron overload based on the correction of the pathophysiological mechanisms of the disease (4).

In Greece, the mean prevalence of beta-thalassaemia is estimated at $7.4 \%$. Its distribution is very uneven and frequencies as high as $15 \%$ have been reported in certain geographic areas (5). For example, in Halkidiki, of 3931 hospitalized patients screened for haemoglobinopathies, $10.8 \%$ were identified as heterozygotes for betathalassaemia (6). Equally, molecular analysis of 199 unrelated patients in south-western Greece confirmed distinct distribution patterns of specific mutations of the HBB gene in the Achaia and Ilia prefectures (7).
According to the National Registry for Haemoglobinopathies in Greece, among 4032 patients registered, the peak distribution among thalassaemia major patients is the 36-45-year-old age group (8). The prognosis for transfusion-dependent beta-thalassaemia patients in Greece has changed with transfusions and chelation therapy, from being fatal in early childhood to becoming a chronic disorder with prolonged survival (9).

Despite regular transfusion and chelation therapy, patients with thalassaemia have an increased mortality rate compared with the general population (10). Heart disease is the most common cause of death, accounting for $51.0 \%$ of total deaths in patients with thalassaemia between 2000 and 2010 and $28.1 \%$ between 2010 and 2015 $(8,11)$. The age of death from heart disease was higher after 2005 than before 2005 (8).

Amid the economic crisis in Greece, reduced resources have had a negative impact on access to health care services mostly due to increases in demand, waiting times and co-payments and the decreased ability to pay for informal payments (12). As ability to pay declines, 
access to care becomes a critical issue, particularly for lowincome and vulnerable groups (13). A series of previous studies investigated the impact of decreased ability to pay, due to the economic crisis, in several patient groups, such as patients with rheumatoid arthritis (14), multiple sclerosis (15) and cancer (16). These studies confirmed that most patients had considerable difficulty in accessing medication, with the most common barriers to treatment being low income, geographical distance from a physician, long waiting lists and a complicated prescription process, in combination with the low availability of medicines in the national health service hospitals. Inequalities in access were also evident in intravenous drug users, diagnosed with hepatitis C virus (17).

Given these findings, and considering the high prevalence and clinical burden of beta-thalassaemia in Greece, the high cost of blood in the country $(18,19)$ and current blood shortages $(20,21)$, we aimed to assess barriers in access to health care services among patients with transfusion-dependent thalassaemia in Greece.

\section{Methods}

\section{Study design}

We conducted a descriptive, observational cross-sectional study. Data were collected during a 3-month period, between November 2018 and January 2019.

\section{Study population and procedures}

Our study sample consisted of beta-thalassaemia patients, who were members of two thalassaemia patient associations, the Greek Thalassaemia Federation, which is an umbrella organisation for all thalassaemia patient associations, and the Panhellenic Association for Patients with Thalassaemia which is the largest thalassaemia patient association in the country. The health care system in Greece is centralized and patient associations are mostly located in Athens, but their members live all over the country (22); therefore, our sample can be considered a national sample.

We used purposive sampling (23) to select study participants, as people with beta-thalassaemia are a special treatment group. We sent an email to the president of the board of directors of each association along with the study's protocol and instrument for approval. Both patient associations agreed to participate in the study. Each patient association sent a participation invitation, an informed consent form, information on the study and a link to the questionnaire to its members. The email clearly stated that patients not currently undergoing transfusion were not eligible to participate. All members aged 18 and over, who were diagnosed with beta-thalassaemia and were transfusion-dependent at the time of the study were eligible to participate.

200 emails were sent out. 46 responses were excluded from the analysis as non-eligible to participate. 38 did not respond. 116 completed the questionnaire in full (estimated response rate $75.3 \%$ ).

\section{Data collection tool}

A questionnaire with the following subsections was developed.

- Participant characteristics: This section recorded anonymized data on the sociodemographic (sex, age, education and marital status) and socioeconomic characteristics (source of income, self-evaluation of financial status and profession) of the participants and their health insurance.

- 5As questionnaire to assess access: We customized and used the Patient Access Partnership 5As framework for measuring access to health care services (24) as a composite tool to measure all elements of access to services related to transfusion (accessibility, adequacy, affordability, appropriateness and availability) among our transfusion-dependent beta-thalassaemia participants.

We defined the transfusion burden as the sum of the burden on the patient and his/her family of each of the following six types of health care services related to having transfusions: (i) transfusion (the actual process), (ii) general health services (outpatient), (iii) general health services (inpatient), (iv) medications (prescription), (v) medications (dispensing) and (vi) laboratory tests. We evaluated each of these elements against the 5As. All items are rated on 5-point Likert scale ranging from 0 (not at all) to 4 (very).

Two bilingual translators translated the scale from English to Greek and back-translated to ensure that the Greek version was equivalent to the original English questionnaire. The questionnaire was then piloted in 30 patients for content and linguistic clarity. The results of the pilot study and the content validity of the questionnaire were evaluated by a group of experts. Patients who participated in the pilot phase were excluded from the final analysis.

\section{Statistical analysis}

We calculated the Cronbach alpha for each of the five subscales (accessibility, adequacy, affordability, appropriateness and availability) to assess internal consistency. As all continuous variables were not normally distributed, we calculated the medians and interquartile range (IQR). We used the Kolmogorov-Smirnov criterion to check for normality as well as graphical representation. For categorical variables (sex, residence, educational level, age, marital status, income, profession, source of income, health insurance status and self-evaluation of financial status), we calculated absolute and relative frequencies. We examined the association between the total score of each subscale and patient characteristics in a univariate analysis using the Mann-Whitney U test or KruskalWallis test with Dunn pairwise tests adjusted using Bonferroni correction.

\section{Ethical considerations}

The study was approved by the institutional board of each participating patient association (Greek Thalassaemia 
Federation 480/3-12-2018 and Panhellenic Association for Patients with Thalassaemia 1/22-11-2018) and was in line with the ethical standards of the Declaration of Helsinki. Participation was voluntary, data were anonymized and informed consent for participation was requested and obtained from all participants.

\section{Results}

\section{Patient characteristics}

Table 1 shows the characteristics of the respondents: most were women (51.7\%), were between 36 and 50 years old $(53.4 \%)$ and lived in urban areas $(82.7 \%)$. Over half $(69.0 \%)$ held a tertiary education degree. Just over $70 \%$ had a monthly income of between 501 and 1500 euros (€), $36.2 \%$ thought that their economic status was bad or very bad, i.e. they faced financial challenges, and $95.7 \%$ were covered by social insurance, while $4.3 \%$ received welfare benefits, which in Greece grant free access to expensive pharmaceutical and hospital care. Due to the sufficiency of coverage, $96.6 \%$ did not have a complementary private insurance plan.

\section{As questionnaire}

The reliability for each subscale was good. The Cronbach alpha was $0.858,0.870,0.905,0.908$ and 0.918 for the subscales of accessibility, adequacy, affordability, appropriateness and availability, respectively. KolmogorovSmirnov normality tests were statistically significant for all subscales.

Table 2 shows the total mean and median scores for the $5 \mathrm{~A}$ subscales and the scores per questionnaire item. The adequacy subscale had the lowest median score (14.0, IQR = 6), followed by availability $(16.0$, IQR = 7) and appropriateness $(16.5, \mathrm{IQR}=6)$ (Table 2$)$. The highest median scores were for accessibility $(17, \mathrm{IQR}=7)$ and affordability $(17, \mathrm{IQR}=8)$.

\section{Accessibility subscale}

Overall, respondents were not faced with overwhelming barriers to accessing health care services in relation to their transfusion. All items in the accessibility subscale had a median score equal to 3 .

\section{Adequacy subscale}

Inpatient health services were rated as less adequate by responders (median 2, IQR $=2$ ) whereas all other health services provided in relation to a transfusion had a median adequacy score of more than 3 .

\section{Affordability subscale}

Outpatient health care services and laboratory tests in relation to transfusions were a substantial financial burden on patients and their families (median 2, IQR = 1). Higher median scores were reported for all other items of the subscale.

\section{Appropriateness subscale}

Inpatient health care services also ranked low in the appropriateness subscale (median $2, I Q R=1$ ), indicating that participants were concerned about the suitability of the inpatient health services they received. All other health care services had higher scores in this subscale.

\section{Availability subscale}

The lowest availability scores were reported for the transfusion unit $(2, \mathrm{IQR}=1)$ and inpatient (median 2, IQR = 2) and outpatient (median $2, \mathrm{IQR}=1$ ) health care services. Higher median availability scores were reported for both for the prescription and dispensing of medication (3, IQR $=1$ for both) and laboratory tests $(3, \mathrm{IQR}=1)$.

\section{Association between subscale scores and patient characteristics}

Correlations between responses and respondent sociodemographic characteristics (Table 3) identified low income and living in rural areas as the main barriers to access to health care services for transfusion-dependent patients. These characteristics were associated with lower scores in almost all subscales.

Participants living in rural areas had significantly lower scores in accessibility (Mann-Whitney $U=468.0$, $P=0.014)$, adequacy $(U=490.5, P=0.036)$, affordability $U$ $=519.5, P=0.011)$, appropriateness $(U=398.0, P=0.005)$ and availability $(U=449.0, P=0.012)$ compared with those living in urban areas.

Furthermore, participants with low incomes had statistically lower scores for adequacy $\left(\chi_{3}^{2}=9.0, P=0.029\right)$ affordability $\left(\chi_{3}^{2}=19.61, P \leq 0.001\right)$ appropriateness $\left(\chi_{3}^{2}\right.$ $=17.70, P \leq 0.001)$ and availability $\left(\chi_{3}^{2}=9.14, P=0.027\right)$ subscales, the association between the total score of the accessibility subscale and income $\left(\chi_{3}^{2}=5.80, P=0.122\right)$ was statistically significantly.

Pairwise comparison indicated that patients with an income of $€$ 1001-1500 a month were less satisfied with the adequacy of the services compared with those with an income of more than $€ 1500(P=0.028)$. Moreover, patients in the lowest income category $(€ \leq 500)$ had significantly lower scores in the appropriateness subscale compared with those in the second income category ( $€$ 501-1000, $P=0.027$ ) or in the highest income category ( $€ \geq 1501, P \leq 0.001$ ). Patients in the highest monthly income category had statistically significant higher scores in the affordability subscale compared with those with a monthly income of $\leq € 500(P \leq 0.001)$, $€ 501-1000$ $(P \leq 0.001)$ or $€ 1001-1500(P=0.007)$. Participants in the highest income category also had better overall score in the availability subscale compared with those with an income of $\leq € 500(P=0.038)$ or $€ 501-1000(P=0.048)$.

On the other hand, participants who self-evaluated their financial situation as very bad/bad scored higher on the affordability subscale than those who evaluated their financial situation as very good/good or average; this difference was marginally statistically significant $\left(\chi_{2}^{2}=5.66, P=0.059\right)$.

\section{Discussion}

We investigated barriers that patients with beta-thalassaemia in Greece may face in accessing the care they require as well as associations between socioeconomic 


\begin{tabular}{|c|c|}
\hline Characteristic & No. (\%) \\
\hline \multicolumn{2}{|l|}{ Sex } \\
\hline Male & $56(48.3)$ \\
\hline Female & $60(51.7)$ \\
\hline \multicolumn{2}{|l|}{ Age group (years) } \\
\hline $26-35$ & $10(8.6)$ \\
\hline $36-50$ & $62(53.4)$ \\
\hline $51-65$ & $39(33.6)$ \\
\hline$\geq 66$ & $5(4.3)$ \\
\hline \multicolumn{2}{|l|}{ Residence } \\
\hline Rural & $19(17.3)$ \\
\hline Urban & $91(82.7)$ \\
\hline \multicolumn{2}{|l|}{ Education } \\
\hline Basic & $13(11.2)$ \\
\hline Secondary & $23(19.8)$ \\
\hline Tertiary & $80(69.0)$ \\
\hline \multicolumn{2}{|l|}{ Marital status } \\
\hline Single & $40(34.5)$ \\
\hline Married/Cohabitating & $60(51.7)$ \\
\hline Divorced & $16(13.8)$ \\
\hline \multicolumn{2}{|l|}{ Health insurance status } \\
\hline Uninsured/Welfare & $5(4 \cdot 3)$ \\
\hline Insured & $111(95.7)$ \\
\hline \multicolumn{2}{|l|}{ Private insurance } \\
\hline No & $4(0.4)$ \\
\hline Yes & $112(96.6)$ \\
\hline \multicolumn{2}{|l|}{ Monthly income (€) } \\
\hline$\leq 500$ & $16(14.2)$ \\
\hline $501-1000$ & $42(37.2)$ \\
\hline $1.001-1500$ & $39(34.5)$ \\
\hline$\geq 1501$ & $16(14.2)$ \\
\hline \multicolumn{2}{|l|}{ Source of income } \\
\hline Salary/Salary with overtime payments & $35(31.3)$ \\
\hline Self-employed & $11(9.8)$ \\
\hline Pension & $66(58.9)$ \\
\hline \multicolumn{2}{|l|}{ Self-evaluation of financial status } \\
\hline Very good/Good & $25(21.6)$ \\
\hline Fair & $49(42.2)$ \\
\hline Bad/Very bad & $42(36.2)$ \\
\hline \multicolumn{2}{|l|}{ Profession } \\
\hline Agricultural, fishery worker & $1(0.9)$ \\
\hline Service worker & $4(3.7)$ \\
\hline Shop and market sales worker & $4(3.7)$ \\
\hline Clerk & $22(20.2)$ \\
\hline Administrative, executive or managerial worker & $2(1.8)$ \\
\hline Scientist, self-employed, technical assistant & $21(19.3)$ \\
\hline Not working or seeking work for first time & $55(50.5)$ \\
\hline
\end{tabular}

factors and access to care. Correlations between responses and respondent characteristics identified low income and living in rural areas as the main barriers to access. Respondents with these characteristics scored lower in almost all questionnaire subscales.

Our findings confirm that respondents are not faced with overwhelming barriers when accessing the transfusion centre or the hospital. However, responses range from being extremely close to home or public transportation to having to use three different means of travel to access the centre. However, accessing outpatient services seems to be harder for more patients, who stated that they incurred additional costs to access private physicians, particularly out of hours. Barriers to accessing pharmaceutical care comes mostly from the fact that in Greece, all medications for an associated condition have to be prescribed by a specialist outside the transfusion unit and this results in additional expense 
Table 2 Scores for the 5 As items

\section{Item}

Accessibility total score

How accessible is the transfusion service that you are receiving treated at?

$3.02(0.78)$

$3.00(1.00)$

How accessible are any general outpatient health services you may be receiving in relation to a

$2.47(0.73)$

$3.00(1.00)$

transfusion?

How accessible are general inpatient health services you may be receiving in relation to a

$2.40(1.05)$

$3.00(1.00)$

transfusion?

How accessible are medications (prescription) you may be receiving in relation to a transfusion?

$2.58(1.16)$

$3.00(1.00)$

How accessible are medications (dispensing) you may be receiving in relation to a transfusion?

$2.78(0.91)$

$3.00(1.00)$

How accessible are laboratory tests you may be having in relation to a transfusion?

Adequacy total score

How adequate is the care you receive in the transfusion unit you are being treated at?

How adequate are general outpatient health services you may be receiving in relation to a transfusion?

How adequate are general inpatient health services you may be receiving in relation to a transfusion?

How adequate are medications (prescription) you may be receiving in relation to a transfusion? How adequate are medications (dispensing) you may be receiving in relation to a transfusion? How adequate are laboratory tests you may be having in relation to a transfusion? Affordability total score

How affordable is the care you receive in the transfusion unit you are being treated at?

How affordable are general outpatient health services you may be receiving in relation to a transfusion?

How affordable are general inpatient health services you may be receiving in relation to a transfusion?

How affordable are medications (prescription) you may be receiving in relation to a transfusion? How affordable are medications (dispensing) you may be receiving in relation to a transfusion? How affordable are laboratory tests you may be having in relation to a transfusion?

\section{Appropriateness total score}

How appropriate do you feel the care is that you receive in the transfusion unit you are being treated at?

How appropriate are general outpatient health services you may be receiving in relation to a transfusion?

How appropriate are inpatient general health services you may be receiving in relation to a transfusion?

How appropriate are the medications (prescription) you may be receiving in relation to a transfusion?

How appropriate are medications (dispensing) you may be receiving in relation to a transfusion? How appropriate are laboratory tests you may be having in relation to a transfusion? Availability total score

How available to you is the care you receive in the transfusion unit you are being treated at?

How available to you are general outpatient health services you may be receiving in relation to a transfusion?

How available to you are general inpatient health services you may be receiving in relation to a transfusion?

How available to you are medications (prescription) you may be receiving in relation to a transfusion?

How available to you are medications (dispensing) you may be receiving in relation to a transfusion?

How available to you are laboratory tests you may be having in relation to a transfusion?

$2.70(0.93)$

$3.00(1.00)$

$14.73(4.98)$

$14.00(6.00)$

$2.43(1.13)$

$3.00(2.00)$

$2.40(0.96)$

$3.00(1.00)$

$2.10(1.15)$

$2.00(2.00)$

2.65 (1.10)

$3.00(1.00)$

2.78 (0.93)

$3.00(1.00)$

2.50 (1.09)

$3.00(1.00)$

15.92 (5.46)

$17.00(8.00)$

3.14 (1.00)

$3.00(1.00)$

2.09 (1.02)

$2.00(1.00)$

2.97 (1.12)

$3.00(1.00)$

$2.74(1.15)$

$3.00(2.00)$

2.65 (1.10)

$3.00(1.00)$

$2.26(1.08)$

2.00 (1.00)

$15.82(4.40)$

$16.50(5.75)$

2.54 (0.94)

$3.00(1.00)$

$2.61(0.80)$

$3.00(1.00)$

$2.31(1.08)$

$2.00(1.00)$

$2.68(0.98)$

$3.00(1.00)$

$2.90(0.85)$

$3.00(0.30)$

$2.46(0.96)$

$3.00(1.00)$

15.06 (5.11)

$16.00(7.00)$

2.45 (1.11)

$2.00(1.00)$

2.32 (1.00)

$2.00(1.00)$

$2.23(1.07)$

$2.00(2.00)$

$2.53(1.06)$

$3.00(1.00)$

$2.73(0.96)$

$3.00(1.00)$

SD: standard deviation; IQR: interquartile range

and time. Respondents were also faced with challenges in accessing laboratory test services and were required to carefully plan the day and time of their visit to ensure access.
The situation is somewhat different when it comes to adequacy of services in the transfusion centre. Responders considered the care they receive somewhat adequate; most of the concerns centred around the 


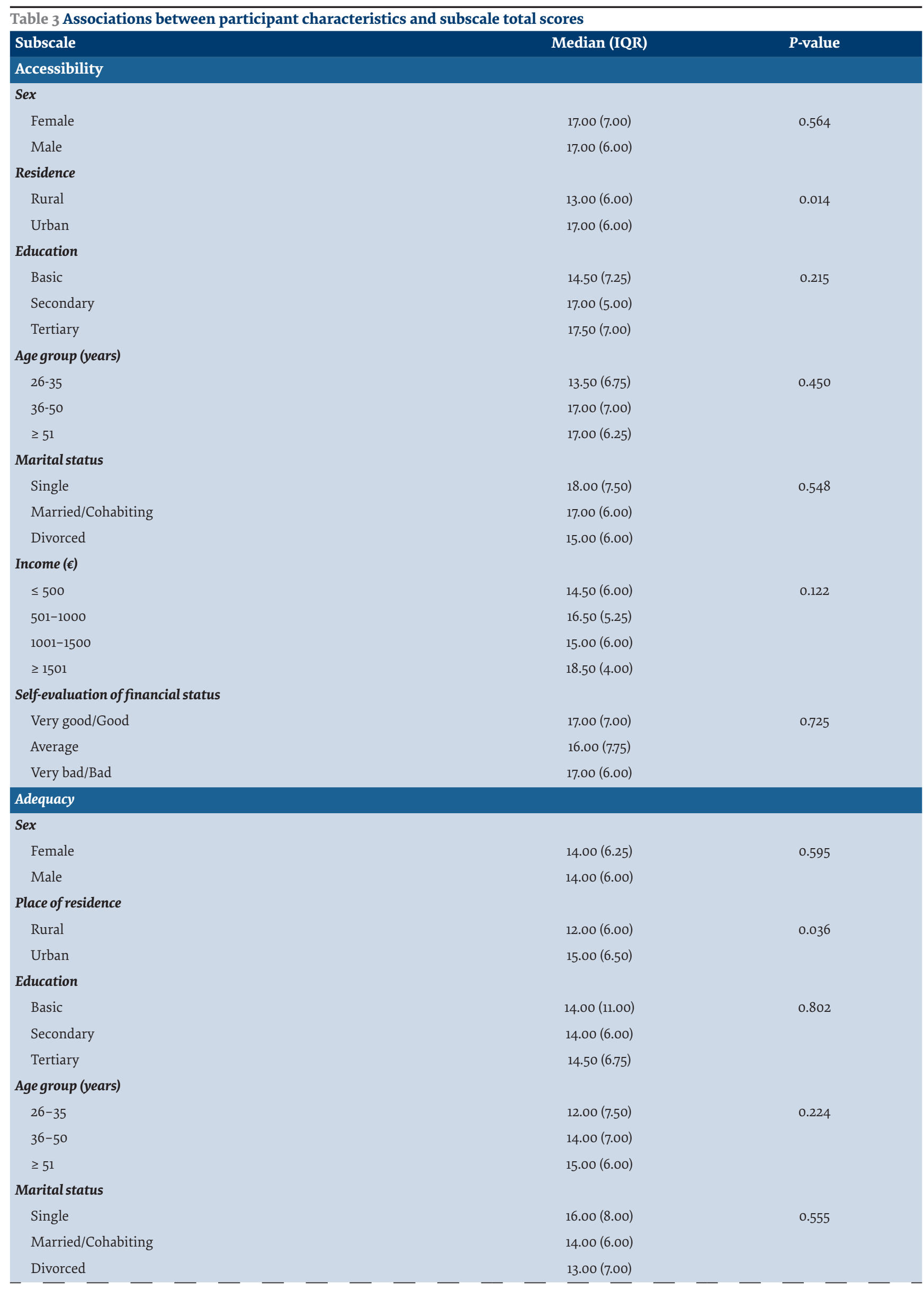




\begin{tabular}{|c|c|c|}
\hline Subscale & Median (IQR) & P-value \\
\hline \multicolumn{3}{|l|}{ Income $(\epsilon)$} \\
\hline$\leq 500$ & $14.00(10.00)$ & 0.029 \\
\hline $501-1000$ & $14.50(6.75)$ & \\
\hline $1001-1500$ & $12.50(7.00)$ & \\
\hline$\geq 1501$ & $17.00(5.75)$ & \\
\hline \multicolumn{3}{|c|}{ Self-evaluation of financial status } \\
\hline Very good/Good & $14.00(7.50)$ & 0.549 \\
\hline Average & $13.00(7.00)$ & \\
\hline Very bad/Bad & $15.00(6.00)$ & \\
\hline \multicolumn{3}{|l|}{ Affordability } \\
\hline \multicolumn{3}{|l|}{ Sex } \\
\hline Female & $17.00(5.50)$ & 0.666 \\
\hline Male & $17.00(8.00)$ & \\
\hline \multicolumn{3}{|l|}{ Place of residence } \\
\hline Rural & $12.00(9.00)$ & 0.011 \\
\hline Urban & $18.00(6.00)$ & \\
\hline \multicolumn{3}{|l|}{ Education } \\
\hline Basic & $12.00(12.00)$ & 0.175 \\
\hline Secondary & $18.00(8.00)$ & \\
\hline Tertiary & $17.00(6.00)$ & \\
\hline \multicolumn{3}{|l|}{ Age group (years) } \\
\hline $26-35$ & $18.00(14.5)$ & 0.754 \\
\hline $36-50$ & $17.00(7.00)$ & \\
\hline$\geq 51$ & $17.00(8.00)$ & \\
\hline \multicolumn{3}{|l|}{ Marital status } \\
\hline Single & $18.00(11.50)$ & 0.670 \\
\hline Married/Cohabiting & $17.00(7.00)$ & \\
\hline Divorced & $17.00(5.00)$ & \\
\hline \multicolumn{3}{|l|}{ Income $(€)$} \\
\hline$\leq 500$ & $14.50(11.25)$ & $\leq 0.001$ \\
\hline $501-1.000$ & $15.00(7.75)$ & \\
\hline $1001-1500$ & $17.00(5.00)$ & \\
\hline$\geq 1501$ & $20.00(2.75)$ & \\
\hline \multicolumn{3}{|c|}{ Self-evaluation of financial status } \\
\hline Very good/Good & $17.50(6.25)$ & 0.059 \\
\hline Average & $16.50(8.50)$ & \\
\hline Very bad/Bad & $18.00(7.50)$ & \\
\hline \multicolumn{3}{|l|}{ Appropriateness } \\
\hline \multicolumn{3}{|l|}{ Sex } \\
\hline Female & $16.00(5.00)$ & 0.381 \\
\hline Male & $18.00(6.00)$ & \\
\hline \multicolumn{3}{|l|}{ Residence } \\
\hline Rural & $13.00(8.00)$ & 0.005 \\
\hline Urban & $17.00(5.25)$ & \\
\hline \multicolumn{3}{|l|}{ Educational level } \\
\hline Basic & $14.00(5.50)$ & 0.558 \\
\hline Secondary & $17.00(6.00)$ & \\
\hline Tertiary & $16.50(5.00)$ & \\
\hline
\end{tabular}




\begin{tabular}{|c|c|c|}
\hline Subscale & Median (IQR) & P-value \\
\hline \multicolumn{3}{|l|}{ Age group (years) } \\
\hline $26-35$ & $15.00(8.50)$ & 0.658 \\
\hline $36-50$ & $16.00(5.00)$ & \\
\hline$\geq 51$ & $17.00(6.00)$ & \\
\hline \multicolumn{3}{|l|}{ Marital status } \\
\hline Single & $17.00(5.00)$ & 0.792 \\
\hline Married/Cohabiting & $16.00(6.00)$ & \\
\hline Divorced & $16.00(6.00)$ & \\
\hline \multicolumn{3}{|l|}{ Income $(\epsilon)$} \\
\hline$\leq 500$ & $12.00(7.00)$ & $\leq 0.001$ \\
\hline $501-1000$ & $18.00(6.00)$ & \\
\hline $1001-1500$ & $16.00(5.50)$ & \\
\hline$\geq 1501$ & $19.00(5.00)$ & \\
\hline \multicolumn{3}{|c|}{ Self-evaluation of financial status } \\
\hline Very good/Good & $15.00(5.50)$ & 0.328 \\
\hline Average & $16.00(6.75)$ & \\
\hline Very bad/Bad & $18.00(5.00)$ & \\
\hline \multicolumn{3}{|l|}{ Availability } \\
\hline \multicolumn{3}{|l|}{ Sex } \\
\hline Female & $15.00(6.75)$ & 0.890 \\
\hline Male & $16.00(7.75)$ & \\
\hline \multicolumn{3}{|l|}{ Residence } \\
\hline Rural & $12.00(10.00)$ & 0.012 \\
\hline Urban & $16.00(6.00)$ & \\
\hline \multicolumn{3}{|l|}{ Education } \\
\hline Basic & $14.50(9.50)$ & 0.425 \\
\hline Secondary & $16.00(5.00)$ & \\
\hline Tertiary & $15.00(7.00)$ & \\
\hline \multicolumn{3}{|l|}{ Age group (years) } \\
\hline $26-35$ & $12.00(9.00)$ & 0.394 \\
\hline $36-50$ & $15.00(6.00)$ & \\
\hline$\geq 51$ & $16.00(8.50)$ & \\
\hline \multicolumn{3}{|l|}{ Marital status } \\
\hline Single & $15.50(7.00)$ & 0.693 \\
\hline Married/Cohabiting & $15.50(6.25)$ & \\
\hline Divorced & $16.50(7.50)$ & \\
\hline \multicolumn{3}{|l|}{ Income $(\epsilon)$} \\
\hline$\leq 500$ & $14.00(9.00)$ & 0.027 \\
\hline $501-1000$ & $15.00(7.00)$ & \\
\hline $1001-1500$ & $15.00(4.50)$ & \\
\hline$\geq 1501$ & $18.50(4.50)$ & \\
\hline \multicolumn{3}{|c|}{ Self-evaluation of financial status } \\
\hline Very good/Good & $15.00(7.50)$ & 0.694 \\
\hline Average & $16.00(7.00)$ & \\
\hline Very bad/Bad & $16.00(7.50)$ & \\
\hline
\end{tabular}

$I Q R=$ interquartile range. 
condition of the blood they receive (particularly if it is fresh or not). Adequacy scores of outpatient and inpatient care were similar. Most problems came from the fact that patients had to carefully plan the time and date of their visit. On the other hand, pharmaceutical care was considered more adequate. Once a prescription is issued, patients feel that they receive adequate care at the point of dispensing.

Access is also largely free at the point of delivery. This is especially true in the transfusion centre and inpatient hospital services, although not as much when it comes to outpatient and laboratory test services, which was reflected on total affordability scores. Equally, even though all thalassaemia-related therapies in Greece are dispensed at a $0 \%$ copayment rate, patients thought that accessing pharmaceutical care placed a disproportionate burden on their or their family's finances.

Despite their long-standing relationship with their physicians and staff at the transfusion centre, patients still felt that the care they receive might not be appropriate and looked for additional information or services elsewhere. In addition, the scores for the appropriateness of inpatient hospital services were low. This possibly comes from the fear that patients are under-transfused because of blood shortages, which is a serious challenge affecting blood transfusions in Greece (20). Patients appear to be happier with outpatient services. This may be largely explained by the fact that they can select their own outpatient care provider, most of the times at a fee paid out of pocket, so they have greater freedom of choice. Equally, responders considered their pharmaceutical care appropriate to a lesser or greater extent.

Responses to the composite measure of availability are important as they may be used to cross-validate responses to other sections of the survey. Lower availability scores in the transfusion centres and in inpatient and outpatient services were mostly due to the long waiting times and the need for careful planning to access those services. Respondents found pharmaceutical care and laboratory tests more available.

While data are limited on access to treatment among thalassaemia patients in Greece, our findings confirm a previous qualitative survey that highlighted barriers in access to pharmaceutical care and diagnostic tests, primarily due to cost (25).

Our findings are also in accordance with previous studies on barriers in access to health care for other chronic diseases, such as rheumatoid arthritis (14), multiple sclerosis (15) and cancer (16), which identified socioeconomic status and distance from urban centres as key contributors to barriers to access. Inequalities in health care were also reported among vulnerable patient subgroups, such as intravenous drug users (17).

To our knowledge, this is the first study that assesses levels of and barriers to access to health care services among patients with transfusion-dependent betathalassemia in Greece and elsewhere. Our study was conducted by email, therefore, patients with no registered email with their patient association could not participate. This may have introduced sampling bias as it is likely that elderly patients with no access to the Internet or no computer skills were not able to participate.

The limited literature on the unmet needs of patients with thalassaemia in Greece may indicate that the widespread availability of oral chelators has reduced the pressure on payers, providers and patients to further advance treatment. Current treatment options are mainly limited to blood transfusion and oral chelation. Research is needed on new treatment pathways, including possibly new treatments, to minimize transfusion burden in the first place.

As advances in the management of beta-thalassaemia are being made, it is important to understand, map and agree on the transfusion burden of patients with betathalassaemia in Greece and elsewhere to realign health policies to deliver measurable improvement in the lives of patients.

\section{Acknowledgement}

We thank the the Greek Thalassaemia Federation and the Panhellenic Association for Patients with Thalassaemia that responded to our call for this research and particularly their members, who shared their perspective and experience with us.

Funding: This work was supported by an unrestricted research grant from the biopharmaceutical company, Celgene (grant number: 3422389/11.04.2018). The funding body had no role in the design of the study, data collection and analysis, interpretation of the data and in writing the manuscript.

Competing interests: None declared. 


\section{Accès aux soins de santé pour les patients thalassémiques en Grèce : étude transversale}

\section{Résumé}

Contexte : La prévalence et la charge clinique de la bêta-thalassémie en Grèce sont élevées. Peu d'informations sont disponibles sur les besoins non satisfaits des patients atteints de bêta-thalassémie et les obstacles à l'accès aux soins.

Objectifs : La présente étude avait pour objectif d'examiner les obstacles auxquels les patients grecs atteints de bêtathalassémie dépendante des transfusions sont confrontés lors de l'accès aux soins, ainsi que les associations entre les facteurs socio-économiques et l'accès aux soins.

Méthodes: Une étude transversale a été menée entre novembre 2018 et janvier 2019. L'échantillon comprenait 116 patients atteints de bêta-thalassémie membres des deux associations de patients panhelléniques pour les personnes atteintes de thalassémie. Tous les répondants étaient dépendants des transfusions. L'enquête a personnalisé et utilisé l'outil Patient Access Partnership 5As of access pour mesurer l'accès des participants aux services de soins de santé (souséchelles:accessibilité, adéquation, accessibilité économique, pertinence et disponibilité). Des données sur leurs caractéristiques socio-économiques ont également été enregistrées. Le lien entre le score total à chaque sous-échelle et les caractéristiques des patients a été examiné à l'aide des tests de Mann-Whitney ou de Kruskal-Wallis.

Résultats : Les répondants considéraient que les services de soins hospitaliers étaient moins adéquats et appropriés et que les services ambulatoires et les analyses en laboratoire étaient plus coûteux. Les services ambulatoires sont également perçus comme moins disponibles. Le revenu des participants était significativement associé à toutes les souséchelles sauf l'accessibilité, et la vie en milieu rural était fortement liée aux cinq sous-échelles.

Conclusions : Les obstacles à l'accès aux soins de santé parmi les patients atteints de bêta-thalassémie qui reçoivent des transfusions persistent, en particulier pour ceux qui vivent loin des centres de transfusion et ont des revenus plus faibles. Il est important de comprendre et de recenser les besoins médicaux et sociaux non satisfaits des patients atteints de bêta-thalassémie en Grèce au moment de l'étude, afin de concevoir et de mettre en œuvre une politique de santé ciblée permettant d'améliorer sensiblement la vie des patients.

$$
\text { كيرياكوس سوليوتيس، كريستينا جولنا، صو فيا نيكو لإيدا البحرية الأبيض المتوسط (الثلاسيميا) في اليونان: دراسة مقطعية }
$$

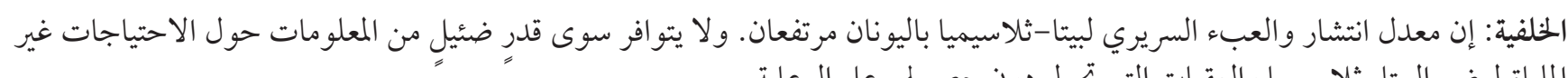
الملباة لمرضى البيتا-ثلاسيميا و العقبات التئي تحول دول دون حصو لمهم على الرعاية.

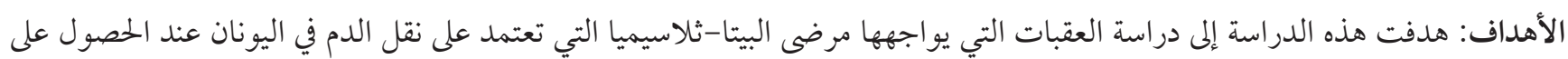

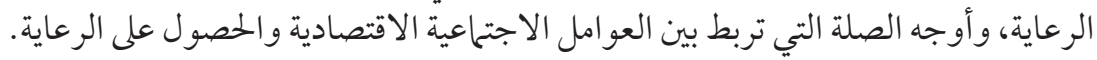

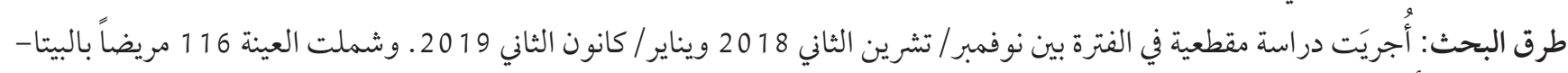

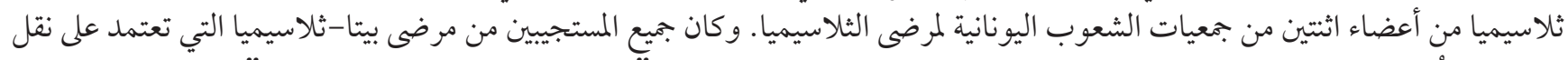

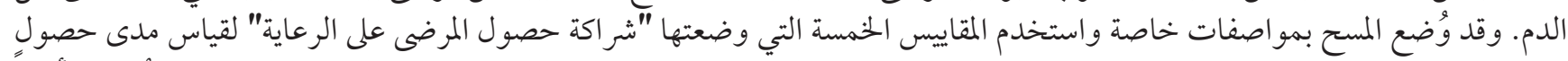

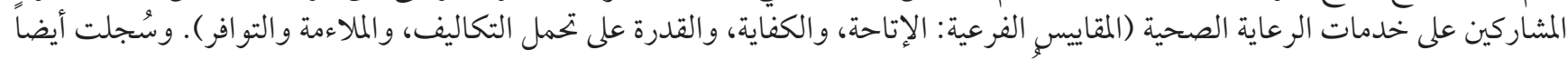

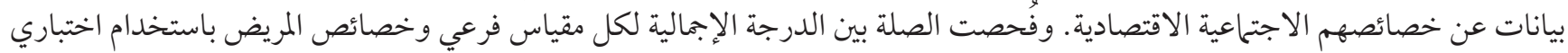
مان ويتني وكروسكال و اليس.

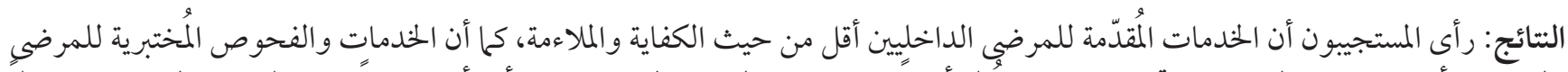

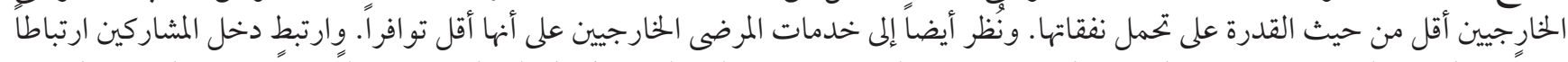

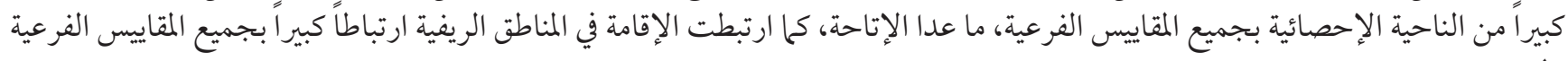

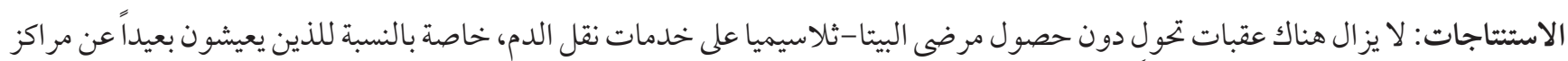

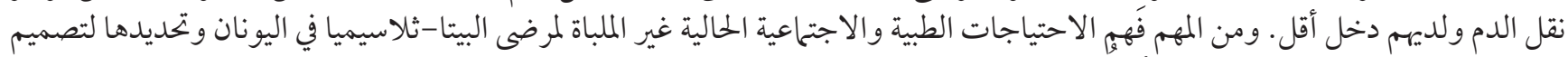

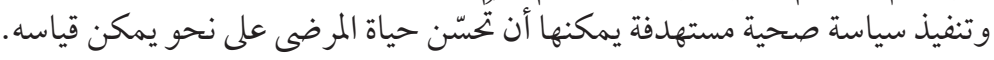




\section{References}

1. Mohamed S. Thalassemia major: transplantation or transfusion and chelation. Hematol Oncol Stem Cell Ther. 2017;10(4):290-8. https://doi.org/10.1016/j.hemonc.2017.05.022

2. Farmaki K, Tzoumari I, Pappa C, Chouliaras G, Berdoukas V. Normalisation of total body iron load with very intensive combined chelation reverses cardiac and endocrine complications of thalassaemia major. Br J Haematol. 2010;148(3):466-75. https://doi. org/10.1111/j.1365-2141.2009.07970.x

3. Angelucci E. Hematopoietic stem cell transplantation in thalassemia. Hematology. 2010;2010(1):456-62. https://doi.org/10.1182/ asheducation-2010.1.456

4. Yannaki E, Stamatoyannopoulos G. Hematopoietic stem cell mobilization strategies for gene therapy of beta thalassemia and sickle cell disease. Ann N Y Acad Sci. 2010;1202(1):59-63. https://doi.org/10.1111/j.1749-6632.2010.05576.x

5. Triantafyllou A, Vyssoulis G, Karpanou E, Karkalousos PL, Triantafyllou EA, Aessopos A, et al. Impact of beta-thalassemia trait carrier state on cardiovascular risk factors and metabolic profile in patients with newly diagnosed hypertension. J Hum Hypertens. 2013;28(5):328-32. https://doi.org/10.1038/jhh.2013.102

6. Kalleas C, Anagnostopoulos K, Sinopoulou K, Delaki E, Margaritis D, Bourikas G, et al. Phenotype and genotype frequency of beta-thalassemia and sickle cell disease carriers in Halkidiki, northern Greece. Hemoglobin. 2012;36(1):64-72. https://doi.org/10.31 09/03630269.2011.642489

7. Papachatzopoulou A, Kourakli A, Stavrou E, Fragou E, Vantarakis A, Patrinos GP, et al. Region-specific genetic heterogeneity of HBB mutation distribution in south-western Greece. Hemoglobin. 2010;34(4):333-42. https://doi.org/10.3109/03630269.2010.4863 54

8. Voskaridou E, Ladis V, Kattamis A, Hassapopoulou E, Economou M, Kourakli A, et al. A national registry of haemoglobinopathies in Greece: deducted demographics, trends in mortality and affected births. Ann Hematol. 2012;91(9):1451-8. https://doi. org/10.1007/s00277-012-1465-7

9. Ladis V, Chouliaras G, Berdoukas V, Chatziliami A, Fragodimitri C, Karabatsos F, et al. Survival in a large cohort of Greek patients with transfusion-dependent beta thalassaemia and mortality ratios compared to the general population. Eur J Haematol. 2011;86(4):332-8. https://doi.org/10.1111/j.1600-0609.2011.01582.x

10. Dede A, Trovas G, Chronopoulos E, Triantafyllopoulos IK, Dontas I, Papaioannou N, et al. Thalassemia-associated osteoporosis: a systematic review on treatment and brief overview of the disease. Osteoporos Int. 2016;27(12):3409-25. https://doi.org/10.1007/ s00198-016-3719-z

11. Voskaridou E, Kattamis A, Fragodimitri C, Kourakli A, Chalkia P, Diamantidis M, et al. National registry of hemoglobinopathies in Greece: updated demographics, current trends in affected births, and causes of mortality. Ann Hematol. 2018;98(1):55-66. https://doi.org/10.1007/s00277-018-3493-4

12. Morgan D, Astolfi R. Health spending growth at zero: which countries, which sectors are most affected?. Paris: Organisation for Co-operation and Development; 2013 (OECD Working Paper N60).

13. Economou C, Kaitelidou D, Kentikelenis A, Sissouras A, Maresso A. The impact of the financial crisis on the health system and health in Greece. Copenhagen: World Health Organization, Regional Office for Europe; 2014.

14. Souliotis K, Papageorgiou M, Politi A, Ioakeimidis D, Sidiropoulos P. Barriers to accessing biologic treatment for rheumatoid arthritis in Greece: the unseen impact of the fiscal crisis - the Health Outcomes Patient Environment (HOPE) study. Rheumatol Int. 2013;34(1):25-33. https://doi.org/10.1007/s00296-013-2866-1

15. Souliotis K, Alexopoulou E, Papageorgiou M, Politi A, Litsa P, Contiades X. Access to care for multiple sclerosis in times of economic crisis in Greece - the HOPE II Study. Int J Health Policy Manag. 2015;5(2):83-9. https://doi.org/10.15171/ijhpm.2015.173

16. Souliotis K, Agapidaki E, Papageorgiou M. Healthcare access for cancer patients in the era of economic crisis. Results from the HOPE III study. Forum Clin Oncol. 2015;6(4):7-11. https://doi.org/10.1515/fco-2015-0020

17. Souliotis K, Agapidaki E, Papageorgiou M, Voudouri N, Contiades X. Access to treatment for hepatitis C among injection drug users: results from the cross-sectional HOPE IV study. Int J Equity Health. 2017;16(1). https://doi.org/10.1186/s12939-017-0601-3

18. Kanavos P, Yfantopoulos J, Vandoros C, Politis C. The economics of blood: gift of life or a commodity? Int J Technol Assess Health Care. 2006;22(3):338-43. https://doi.org/10.1017/s0266462306051233

19. Fragoulakis V, Stamoulis K, Grouzi E, Maniadakis N. The cost of blood collection in Greece: an economic analysis. Clin Ther. 2014;36(7):1028-36.e5. https://doi.org/10.1016/j.clinthera.2014.05.003

20. Marantidou O, Loukopoulou L, Zervou E, Martinis G, Egglezou A, Fountouli P, et al. Factors that motivate and hinder blood donation in Greece. Transfus Med. 2007;17(6):443-50. https://doi.org/10.1111/j.1365-3148.2007.00797.x

21. Hauk L. Severe blood shortages reinforce the importance of reducing wastage. AORN J. 2018;107(5):P4. https://doi.org/10.1002/ aorn.12160

22. Souliotis K, Peppou L, Agapidaki E, Tzavara C. Health democracy index: development and validation of a self-reported instrument for measuring patient participation in health policy. Front Public Health. 2018;6. https://doi.org/10.3389/fpubh.2018.00194

23. Lepkowski J. Sampling the difficult-to-sample. J Nutr. 1991;121(3):416-23. https://doi.org/10.1093/jn/121.3.416

24. Souliotis K, Hasardzhiev S, Agapidaki E. A conceptual framework of mapping access to health care across EU Countries: the Patient Access Initiative. Public Health Genomics. 2016;19(3):153-9. https://doi.org/10.1159/000446533

25. Economou C. Barriers and facilitating factors in access to health services in Greece Copenhagen: World Health Organization, Regional Office for Europe; 2015. (http://www.euro.who.int/_data/assets/pdf_file/ooo6/287997/Barriers-and-facilitating-factorsin-access-to-health-services-in-Greece-rev1.pdf?ua=1, accessed 3 March 2019). 